\title{
A New Approach to School Management: Determination of Student Related Risks According to the Internal Control ${ }^{*}$
}

\author{
Sevilay Şahin ${ }^{1}$, Ömer Faruk $\mathrm{Ak}^{2, *}$ \\ ${ }^{1}$ Department of Educational Sciences, Gaziantep University, Gaziantep, Turkey \\ ${ }^{2}$ Educational Sciences Ph.D. Student, Gaziantep University, Gaziantep, Turkey
}

Copyright $\bigcirc 2018$ by authors, all rights reserved. Authors agree that this article remains permanently open access under the terms of the Creative Commons Attribution License 4.0 International License

\begin{abstract}
The head department of the Ministry of National Education and affiliated schools have been carrying out strategic planning for the last 10 years in order to make the right decisions and implement them and increase the efficiency of the institution for the purpose of reaching their future goals. In order for strategic planning by schools to be effective, the basis of the identified strategies needs to be realistic and reliable. Nevertheless, it is important in terms of efficient management of schools to pin down any potential threats and bottlenecks that might prevent the achievement of future goals and objectives or identify any sorts of risks that are described as opportunities that facilitate the achievement of these goals and objectives. Internal control, which is a form of management based on strategic plans and risks and which is seen as parts of a whole complementing each other, has been put into effect pursuant to Law No. 5018. The purpose of this study is to carry out situation analyses more effectively and efficiently within the context of strategic planning in schools and to ensure that school principals, teachers, parents, and students are able to determine the risks related to students in order to correctly identify the strengths and weaknesses of schools as well as opportunities and threats using qualitative research methods besides creating a risk pool for schools. According to the findings obtained as a result of the research, the risky situations were reached under these headings: "Technology and internet addiction Aimlessness, lack of motivation, Academic Procrastination (laziness) - Lack of discipline / Self-discipline problem, Impertinence - Violence, Disrespect, Rudeness - Smoking, alcohol and substance addiction- Suicide - Communication problems". By taking into account these risks, the risk pool will be created and possible measures will be taken without any further adverse effects, and schools will be better managed.
\end{abstract}

Keywords Student, Risk, School Management,
Internal Control, Strategic Plan

\section{Introduction}

As a result of globalization and competition among institutions, institutions in our country have been in search of new management styles in the same way institutions in many other countries have been. The main purpose of such quests has been to find out how to improve efficiency. The structure and functioning of schools are different from those of other institutions and businesses because of the fact that human is the main element of schools which aim at presenting educational activities in a qualified manner and enable all students to benefit from these activities. Considering that there will be no compensation for some of the consequences that will arise if the decisions taken in school are wrong, it is understood that it is important to make and implement the right decisions to the schools.

School administrators, who have the authority to use resources effectively in order to reach their goals and to make planning about the school, need to plan within a certain strategy in order to achieve the goals of the school and transform the school into a learning center [1]. According to both classical and modern management theories, the prerequisite for making the right decisions is to make a reasonable data-based planning for the activities to be done.

According to the Public Financial Management and Control Law numbered 5018 entered into force in 2003, there is a requirement in the schools attached to the Ministry of National Education as well as in all the public institutions to prepare a strategic plan in order to measure and evaluate the performances according to the pre-determined criteria in line with the current legislation and basic principles, to establish the vision and missions 
related to the institution's future and to determine strategic goals and measurable targets. In this regard, the central organization and the affiliated schools of the Ministry of National Education are making strategic decisions to give the right decisions and to implement these decisions for increasing the effectiveness and efficiency of the institution for more than 10 years.

Strategic planning is a long-term plan that takes into consideration both the institution's internal environment and the external environment outside the institution's control in regards to problems which may negatively impact the development of the institution. In order for strategic planning to be effective, the basis of the identified strategies need to be realistic and reliable since they are holistic approaches. In addition, the holistic structure of strategic planning stems from the fact that a planning process is implemented whereby both strengths and weaknesses associated with the organization and threats and opportunities arising from the organization's external environment are assessed all together as well as entailing full support from the management of the organization and the staff at all levels [2].

According to Akyüz [3], the planning of education is a long-term process. Strategic planning is a more appropriate type of planning for educational institutions than other types of planning since strategic planning is also a long-term planning process. That's because strategic planning describes the path between an institution's position and the point it wants to reach.

Strategic planning ensures communication, participation, different values and interests, making appropriate analytical decisions, facilitating accountability and applying these attributes successfully. Strategic planning provides great benefits for institutions and businesses as it is a disciplined work that determines the overall strategic goals and objectives, questions what an organization or business is doing and why it does it, chooses appropriate policies for the acquisition and distribution of resources by producing key decisions and actions, and functions as a guide $[4,5,6]$.

There are a number of problems in the implementation of the strategic plan that has been emphasized theoretically. It is difficult to say that strategic plans, which have to be prepared and enforced in all schools according to the legislation in force, are functionally prepared, and the implementation processes are carried out appropriately.

Many studies [7, 8, 9, 10,11, 12, 13, 14, 15], have revealed that strategic plans are not made properly, the current situation of schools and their strategic plans are inconsistent and that studies carried out within the scope of preparation of strategic plans are solely on paper and that the phases of strategic plan implementation do not fully and accurately serve the foreseen objectives $[16,17]$.

Ereş [18], defines educational strategy as a mode of action that an educational institution would implement to achieve its goals and objectives. The general objectives, purposes, and duties of educational institutions are set out in the Basic Law of National Education and other relevant legislation. The methods that can be employed to accomplish these objectives, purposes, and duties are set out in the statutes of each educational institution. What is important at this stage is the chosen method in the process of reaching the set goals and how functional these methods are. When the problems plaguing our education system and the methods applied to solve these problems are evaluated, it becomes apparent that the strategies used in our education system are not functional enough.

Since educational institutions are not managed like other institutions or private businesses, the strategic plans prepared by educational institutions differ from strategic plans made in other fields [19]. For this reason, employees and shareholders must certainly participate in the strategic planning process of educational institutions. Otherwise, the prepared planning model will not be strategic as strategic planning is about reconciliation, harmony and continuous communication. The success potential of a non-strategic plan randomly prepared is disputable [18].

Strategic planning is also a managerial tool used to manage uncertainties and risks, as strategies are essentially choices with both effective and risky consequences. Successful strategic planning should be able to help the organization position itself to ensure that it benefits from opportunities while protecting it against threats, uncertainties, and risks. In that regard, it is necessary to understand what is going on inside and outside the organization and, if necessary, to reshape it [20].

The right decision-making process for the actions to be taken is closely related to the two propositions of "doing a job right on first try" and "preventing errors and omissions before they happen". For this reason, with regards to the decision-making process, it is necessary to make the right forecasts and determine in advance the actions to be taken in case a crisis situation occurs, and minimize possible setbacks and maximize the opportunities [21]. It is easier to produce a strategy when an organization is ready for eventualities. As future scenarios are more concretely defined and become more visible, the likelihood of making the right decisions about which strategies to work on will increase [20].

This is where the concept of risk emerges. The concept of "risk" is of great importance in terms of effective and efficient use of the resources of the institution. Literally, risk means the possibility of an event occurring and being influenced by it [22]. Whereas in the legislation, risk is defined as: "a situation or events that may prevent public administrations achieving their institutional and strategic objectives, or prevent them from functioning by causing unexpected damage". [23]

When assessed in general terms, even though risk is defined as negative situations and uncertainties that may be faced in the future and prevent achievement of objectives and goals, it is also defined as an opportunity that may also 
facilitate the achievement of those same objectives [21].

There are many different definitions and many types of risk in the literature about risk and risk types. We can divide the risks facing educational institutions into two, based on the premise that institutions and organizations in different sectors should focus on different risks and types of risks that fit their needs. These are internal and external risks.

Internal risks are risks that arise from events that the organization or individuals can directly control. External risks are risks that arise from events that the organization or individuals cannot directly control.

The question of "How should risks determined and evaluated by institutions is managed?" emerges according to these definitions and classifications.

According to Alptürk [24], when an institution manages its existing risks, two types of paths can be followed which are completely different from each other. The first is to manage the existing risks one by one, and the second is to manage all of the risks in the framework of the risk management program, seeing them as part of a spectrum. The second method is also called "Internal control" in general.

A committee called the Committee of Sponsoring Organizations of Treadway Commission (COSO) founded in 1992 in the USA published a report called "Internal Control: Integrated Framework", which stated that the purpose of internal control was to help the management make the right decisions, make the institution run effectively and efficiently, to help employees act in accordance with the relevant legislation, and report the results of all financial and non-financial activities at a reliable level.

The internal control components have been developed based on the cube-like management model shown in Figure 1 , which is called the COSO Cube. There is a direct relationship between institutional aims and objectives and internal control elements. All units within an organization benefit from five components of internal control (control environment, risk assessment, control activities, information and communication and monitoring) to achieve the objectives of effectiveness and efficiency of activities, information reliability and legal compliance

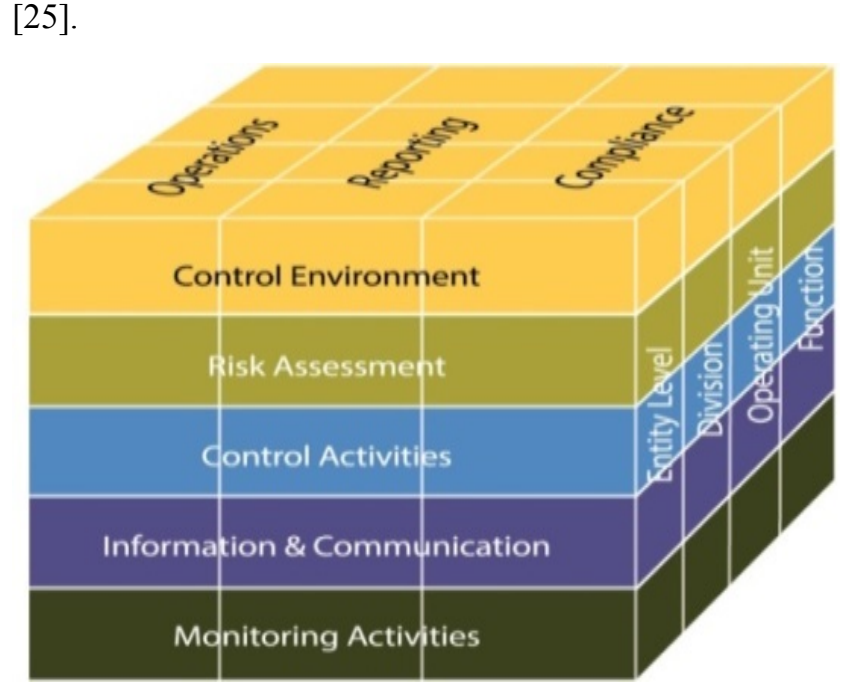

Figure 1. COSO Cube

The COSO Internal Control Model has initially been used by the private sector and for management practices in financial areas but has since been expanded to cover all sectors and all activities [26].

According to the COSO Internal Control Model, the effectiveness and dynamics of the institutional control processes are based on the answers to the five questions listed below [27].

- Do we have the infrastructure to control the performance of our duties? (Control Environment)

- Are we able to identify the risks that may prevent the performance of our duties? (Risk Valuation)

- Have we implemented appropriate control activities against risks that may prevent performance of our duties? (Control Activities)

- Have control messages and ideas been communicated to all units across the institution from top to bottom and from bottom to top? (Information and Communication)

- Do we have an overview of how the activities are controlled? (Monitoring)

Internal control components and Public Internal Control Standards are shown in Figure 2. 


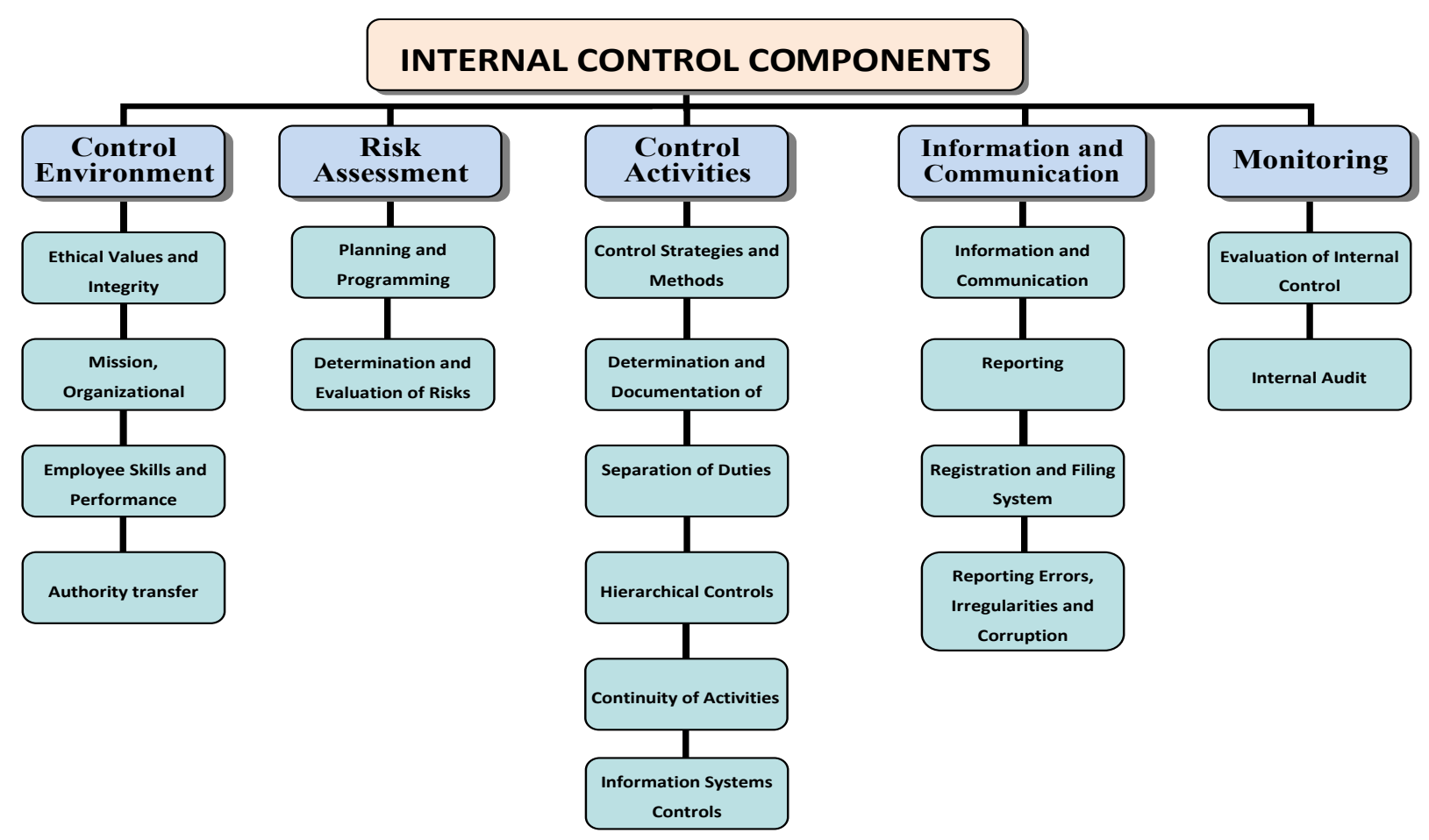

Figure 2. Internal Control Components and Public Internal Control Standards

In the following years, the COSO Internal Control Integrated Framework has started to be widely used in the public and private sectors in many countries for effective management. The COSO Internal Control model, the most widely used model in international field risk management models, has also been adopted as a risk management model in our country [28].

Since 2003, legislative arrangements have been made in the related fields and efforts have been made to improve the functionality of internal control systems in all public institutions in line with these regulations. For example, the 6th article of the Communique on Public Internal Control Standards issued in this context, which is named the "Determination and Evaluation of Risk", reads "Administrations should systematically analyze internal and external risks that may prevent the achievement of their goals and objectives and determine the measures to be taken" [29]. It is understood from this that if the public institutions are to be managed well, all institutions need to complete the internal control standards as soon as possible.

Internal control, which is composed of many interconnected elements, is a managerial tool for ensuring the management achieves its goals and objectives. Internal control is not a single event or situation but a chain of actions that have penetrated into institutional activities [30]. In this context, the risk management activities of administrations need to be carried out simultaneously with the strategic planning and performance program preparation studies.

Institutions first set targets in the framework of their risk appetites, establishing a balance between the risks and the objectives that will enable the strategic goals stated in the strategic plan to be achieved [25]. The risk appetite mentioned here refers to the highest risk level which the administration is ready to take in accordance with its objectives. The concept of risk appetite means that the risks above this level cannot be accepted and that measures need to be taken.

The Risk Management Cycle (Detect, Evaluate, Reply, Report, Review) should be considered at all stages of the strategic plan preparation phase, beginning with the determination of the targets and ending with the analysis of whether or not the targets have been achieved as foreseen [25,31]. In addition, analyzing various possibilities that may create risks through risk management tools will help the institution keep its risks within a manageable range during the strategic planning process [20].

Institutions may manage these risks in different ways after determining the risks that may occur in their field of activity through appropriate methods. One of the most important points for effective management of risks through internal control is the identification and rating of risks by the employees of the institution at all levels. It is then necessary to make a decision on acceptance, control, transfer, and avoidance of risks according to this rating, and to develop forward-looking management strategies accordingly. Internal control, which is already a self-controlling system during the realization of activities, is an internationally developed management tool integrated with planning, organizing, directing and auditing (control) functions specified in management theories and developed according to interactive, systematic and specific standards used by administrations [32].

With its modern aspects, internal control has gained 
prominence in the management of public institutions in our country through the widespread adoption of the New Public Management approach, which is defined as the adoption by the public sector of private sector management principles [33].

In order to establish an effective risk management system through internal control within an institution, it is a prerequisite that the standards specified in the institution's control environment component are met. Afterwards, the risks that may arise within the institution should be determined by using appropriate methods and prioritization should be done by evaluating the determined risks. Then, it is rather crucial to determine what risks will be managed in which ways, and how to turn these risks into opportunities by determining the future control strategies that will be employed to that end. The institution will not be managed effectively and efficiently as it will not be possible to use the human and material resources efficiently if the determination and rating of the risk is not done properly.

Effective participation of the employees and stakeholders of the organization is considered extremely important for correct identification and assessment of risks because participation is an important factor in understanding opportunities and threats. The stronger the participation is, the higher the performance shown for reaching the solution. Through participation, participants play an active role in ensuring compliance and achieving the desired solution, which eliminates the possibility of encountering resistance seen against imposed solutions [34].

Furthermore, in order for the internal control system to keep functioning properly, it is necessary to constantly monitor and correct any disruptions in accordance with the audit standards using the internal audit function. The internal audit function, which is part of internal control monitoring, is a contemporary type of auditing method conducted with a focus on risk assessment (starting from high-risk processes) according to internationally accepted standards and on the basis of the principle of guidance. This way, it is ensured that the risky situation is detected in advance and removed [35].

In sum, it can be said that internal control, which helps achieve the foreseen goals in the strategic plan and embodies both risk-based management and supervision is very useful for organizations.

\section{Objectives}

Despite the publication of the internal control standards in the Official Gazette about 9 years ago in our country, it is known that many institutions do not yet have these standards and have not even heard of them. Internal control and strategic planning were published in the same law together as parts of a whole complementing each other. In all public institutions as well as in schools affiliated to the
Ministry of National Education, the detection of risky areas that may prevent the ministry from reaching its general and specific purposes and the establishment of school administrations in accordance with the internal control stated in the law numbered 5018 is supposed to fill an important gap.

The purpose of this study is to carry out situation analyses more effectively and efficiently within the context of strategic planning in schools and to ensure that school principals, teachers are able to determine the risks related to students in order to correctly identify the strengths and weaknesses of schools as well as opportunities and threats besides creating a risk pool.

By means of this risk pool, the strategic plan will help the school administration achieve the specified goals and also affect the education processes at school in a positive way.

Risks related to the students who are the research subject will be examined in two parts as internal risks and external risks. The risks that occur as a direct consequence of students' behavior and are identified as internal risk will be the focal point of the research. External risks which depend on the factors occurring regardless of the students themselves will be outlined in general.

The study seeks the answer to the following questions:

1. What are internal risks that may affect students at school?

2. What are the external risk areas that students can affect at school?

\section{Materials and Methods}

The research is a qualitative study to determine the risks that may affect students at school according to the views of school principals, teachers, students, and their parents. Qualitative research is a study of the whys and wherefores of human behavior. Qualitative research has been carried out for the purpose of describing the data with detail and in depth. Since the qualitative method has been used in the study, extensive descriptions have been provided. Qualitative research investigates all factors related to the situations examined with a holistic approach [36]. An individual or situation-based approach has been adopted in the study using a phenomenological design. Research based on facts that we are aware of but we do not have a detailed and in-depth understanding of is called phenomenological research (phenomenology) design. Phenomenological research aims at revealing and interpreting individual perceptions or perspectives related to a particular phenomenon [36].

\subsection{Study Group}

5 school principals, 5 assistant principals, 5 teachers working in state schools under Niğde National Education 
Directorate as well as 5 parents and 5 students constitute the study group, having volunteered to share their opinions. The research was carried out in April, May, and June of 2017.

School principals, assistant principals, teachers and student parents and students from different kinds of schools have been selected for interviews for the best research results. In the study, different types of schools were taken into the study group according to the sampling method used in qualitative research studies and the maximum diversity sampling was used in order to increase the representative power of the target group. At the same time, the method of situation sampling has also been used to make the research more practical and speed up the research process. The maximum diversity sampling aims to create a relatively small sample and reflect the diversity of the individuals that may be partial to the problems studied in this sample [36].

For this purpose, the research includes school personnel with diverse roles and seniority levels from a variety of schools. Within the scope of the research, a total of 25 participants, including 5 school principals, 5 assistant principals and 5 teachers working in 5 different type of schools (high schools) as well as 5 parents and 5 high school students, were interviewed. Of the interviewed participants, 5 are affiliated with Anatolian High schools (1 male principal, 1 male assistant principal, 1 male teacher, 1 female student, 1 female parent), 5 with Science High schools, (1 male principal, 1 male assistant principal, 1 male teacher, 1 female student, 1 female parent), 5 with Multi-Program High Schools (1 male principal, 1 female assistant principal, 1 male teacher, 1 female student, 1 male parent), 5 with Vocational and Technical Anatolian High Schools (1 male principal, 1 female assistant principal, 1 female teacher, 1 male student, 1 male parent), and 5 with Anatolian Religious Vocational High Schools (1 male principal, 1 male assistant principal, 1 female teacher, 1 male student, 1 male parent). Nine of the participants in the study group are female and 16 are male. Of the female participants, 2 of them are assistant principals, 2 of them are teachers, 2 of them are parents and 3 of them are students. Of the male participants, 5 of them are principals, 3 of them are assistant principals, 3 of them are teachers, 3 of them are parents and 2 of them are students. 8 of the school principals and teachers in the study group have 1 to 10 years, 5 of them have 11 to 20 years, and 2 of them have over 21 years of experience.

\subsection{Data Collection Tools}

In this study, the semi-structured interview technique has been used as the data collection method. The semi-structured interview technique is neither as rigid as fully structured interviews nor as flexible as unstructured interviews. They stand somewhere in the middle [37]. Prior to the preparation of the interview questions, the national and international literature on the research topic was searched and then the questions planned to be included in the form were determined and the "Questionnaire Form for Determining Student-Related Risks" was developed. Accordingly, participants were asked "What are risks that may affect students at school?" and two lecturers, an inspector, two school principals and a teacher were interviewed to evaluate the meaning, purpose, and scope of the following sub-questions "Are the said risks related to events that are within or beyond the students control" and "Why do these risks occur", and to ensure content and view validity. In the course of the process, a trial questionnaire was applied to a principal, a teacher and a parent to determine whether the questions were understood correctly and we gave the questionnaire its final shape on the basis of the obtained information.

Prior to the interview, participants were informed about the research and made aware of its significance and their permission was asked to use a voice recorder in order to avoid data loss during the interview besides taking notes. Participants were informed that they could listen to the interview records and remove a part or all of the statements they made during the interview when necessary. This allowed us to prevent any negative aspects regarding the recording device and voices of the participants who gave consent were recorded. We have tried to create an environment where participants could express themselves comfortably and we gave them the survey questions only after we had the feeling that they were feeling comfortable with their responses noted down throughout the entire interview.

\subsection{Analysis of the Data}

In the analysis of the data, the content analysis method was used and the data were analyzed in four stages. According to this, the data gathered from the participants were organized and coded, the themes were formed from the coded data, the codes and themes were organized and clarified, and the probable risks were defined and the findings were defined and interpreted [36].

The analysis of the opinions of the participants was carried out in accordance with the general framework of the qualitative analyzes examined by Miles and Huberman [38] in three sections as data reduction, data presentation, conclusion and validation in addition to the stages of coding, establishing themes, reconstruction of data according to codes and themes, and interpretation of findings by Yıldırım and Şimşek [36]. A flexible approach was followed in the context of the specificity of each research. The notes and voice recordings held during the interviews were deciphered and analyzed, and groupings were made according to the similarity of the opinions expressed about the subject.

School administrators, teachers, parents, and students who participated in the research were shown by abbreviations. The data obtained by the interview technique were quantified and expressed as frequency for 
each theme. A detailed report of the data and an explanation of how the results are achieved in the research is one of the important criteria for qualitative research [36].

In this regard, in order to ensure the internal validity of the research, groupings were made according to the similarity of the declared statements and then the data were coded according to this similarity. Number of participants and frequency of expression were taken into account when coding.

The expressions encoded in the first stage were revised and classified according to similarities and differences, and some expressions irrelevant to the subject were sorted out by considering that they would not contribute.

It was paid attention that the coded data are compatible with the themes to include significance and integrity that the themes are capable of explaining the data collected within the scope of the research and that the different themes also build a meaningful whole within themselves.

Each researcher tried to clarify the theme in his own process. In the first stage, roughly formed groups of expression were repeatedly examined by a meticulous study. Then the coding, the themes, and the risks were clarified to reach the top level of conceptualization.

It was paid great attention to preserve the authenticity of the expressions and not to let the authors add personal comments in setting the codes, creating the themes and clarifying the risks.

The data were analyzed by two researchers during the stages of coding, defining themes and determining the risk phrases from the generated themes. The findings of two researchers as to whether or not the theoretical framework is consistent with the findings are compared by referring to a specialist examination, and the relation of the concepts with each other and other themes has been evaluated in respect of the compatibility and consistency. The findings of the study were found to be consistent with previous predictions, and the findings were shared with some participants and found to be realistic. Interviews were recorded, detailed explanations as to how the results were achieved and direct citations were presented to prove the transferable characteristics of the study for similar environments and to increase the credibility.

Consistency between coders is usually calculated to determine the reliability of the content analysis. Taking into account the principle that quantification of qualitative data will increase reliability [36], the correspondence of the two researchers' codes and themes was examined, the number of agreements and disagreements was determined, and the internal reliability of the study was calculated using the formula "Reliability = agreement / (agreement + disagreement)" [38].

As a result of the reliability calculation, the item match percentage was found to be 0.88 . According to Miles \& Huberman [38], if the percentage of item match between researcher evaluations is about or over $90 \%$, a desired level of reliability is achieved.
At the end of the interview, the researchers provided external reliability by showing the participants the notes taken during the interview to compare the data with the participants' own perceptions.

Each step in the research process was explained in detail and comparisons between the theoretical information in the field and the current practice reality were made in order to ensure the external validity of the research and to be tested with other research.

In brief, to explain at the conceptual and relational level, the qualitative data were firstly coded and themes were created; the themes were interpreted in an understandable way paying attention that they are objective, distinctive, fit for the research purposes and have integrity within themselves [36, 39].

\section{Results}

The findings section consists of two parts. The first part contains internal risks related to events within students' control, while the second part contains external risks related to the events outside the control of students.

When the data from the interviews on the internal risks that may be related to the events that the pupil can directly control are analyzed, it was possible to theme under seven groups such as "Technology and internet addiction Aimlessness, Lack of motivation, Procrastination (Laziness) - Indiscipline/Self-discipline problem, Impertinence - Violence, disrespect, rudeness - Smoking, alcohol and substance addiction - Suicide Communication problems, lack of or excessive confidence".

The first theme "Technology and Internet addiction" is formed of the encoded data as "mobile phone, tablet, internet, computer, game, device, TV, addiction, film, technology, line, device, flow speed, security, curriculum, getting bored, sparing time, busy with more than one thing, correspondence, chat, opium and task interruption ". Risks that may arise under the theme of technology and internet addiction are listed in Table 1a.

Table 1a. Internal risks that may arise in the context of "Technology and internet addiction" related to students

\begin{tabular}{|c|c|c|}
\hline Theme & Risks & Freq. \\
\hline $\begin{array}{c}\text { Technology } \\
\text { and internet } \\
\text { addiction }\end{array}$ & $\begin{array}{l}\text { Students do not spend enough time and do } \\
\text { not focus on their lessons due to their } \\
\text { addiction to games on technological devices } \\
\text { (PC, mobile phone, tablet), } \\
\text { Children who excessively use technological } \\
\text { devices such as computers, mobile phones, } \\
\text { televisions and who are accustomed to the } \\
\text { speed of programs on these devices find the } \\
\text { learning activities in the classroom boring, } \\
\text { Students who are overly interested in social } \\
\text { media and constantly engaged in messaging } \\
\text { are bored by actual social interactions in real } \\
\text { life, }\end{array}$ & 12 \\
\hline
\end{tabular}


As seen in Table 1a, which shows student-related internal risks that can occur at schools, 12 of the participants stated that the technology dependency was a serious risk for the students. Some of the participants' views on this issue are as follows;

7Assistant Principal, F, Science High School; “The mobile phones that parents give their children due to safety concerns are the opium of today's society. If a student is to have a mobile phone, it should be an old model without internet access and limited allowance."

14Teacher, M, Multi-Program High School; "Children are constantly watching movies on the internet or TV when they are not at school. The medium through which they watch those films, and the internet itself, it is a fast data-streaming environment. Despite changes in curriculum, they cannot keep pace with the speed of the internet or the movies. And that is precisely why students get easily bored with stuff in real life."

4Principal, M, Anatolian High School; "In my opinion, one of the most important risks for students in this era is technological devices like mobile phone, tablet, computer. They barely have enough time for their lessons as they never let go of them."

18Parent, F, Science High School; "Young people love to be busy with more than one thing at the same time. You see a child watching a movie on TV while texting his or her friends on a mobile phone or tablet or playing games and eating snacks or drinking at the same time. They also like chatting if there are other people around. They are kind of multi-tasking but nothing actually gets done."

15Teacher, F, Religious Vocational High School; "There are students who won't let go of their phones even during the lessons. We hear it on the news, how children kill or get killed because of the games. Technology addiction, like other addictions, keeps children away from nature."

The coded data that constitute the second theme "Aimlessness, Lack of Motivation, Academic Procrastination (Laziness)" are as follows: "Lack of motivation, lack of planning for the future, not specifying individual goals, lack of emphasis on education, reward, reading habit, weakness in reading comprehension, lesson, examination, irrelevant answers, intelligence, reluctance to study lessons, assignments and tasks, making excuses, avoiding studying, indifference to lesson, being too familiar, not doing homework and duties, doing spontaneously, student, not getting feedback and not understanding of subjects". The risks that may arise under this theme are listed in Table 1-b.
Table 1b. Internal risks that may arise under the theme of "Aimlessness, lack of motivation, academic procrastination (laziness)"

\begin{tabular}{|c|c|c|}
\hline Theme & Risks & Freq. \\
\hline $\begin{array}{l}\text { Aimlessness, } \\
\text { Lack of } \\
\text { motivation, } \\
\text { Procrastination } \\
\text { (Laziness) }\end{array}$ & $\begin{array}{l}\text { - Students who do not have goals and } \\
\text { career plans for the future do not care } \\
\text { enough about their school education, } \\
\text { Students who delay doing their } \\
\text { homework or the tasks given to them or } \\
\text { avoid doing them have a hard time } \\
\text { understanding their lessons, } \\
\text { Students not familiar with the methods } \\
\text { and techniques of learning that fit their } \\
\text { own learning style easily get bored due } \\
\text { to difficulties with learning } \\
\text { Students who do not read books are } \\
\text { affected negatively by their inability to } \\
\text { understand what they read, }\end{array}$ & 10 \\
\hline
\end{tabular}

Ten of the participants said that students were not motivated enough and that the fact that they were putting off their responsibilities and not studying their lessons was a risk. Some of the participants' views on this issue are as follows.

6Assistant Principal, F, Multi-Program High School; "I sometimes ask the students about their future plans when I talk to them. And most of the time I hear that they do not have any plans at all. Students with no goals to push them do not care enough about their school education or study their lessons."

12Teacher, M, Anatolian High School; "Many topics in the new curriculum consist of tasks and assignments that students need to do on their own. And we get nothing in the shape of a finished project or homework from students even though we give them these tasks or assignments leading to students not developing an understanding of the subject matter at hand."

16Parent, M, Multi-Program High School; "When we tell our child to go to his room and study, he just won't. We cannot get him to do his homework or study his lessons. He always finds a way of avoiding his school responsibilities by making up excuses. He just ends up doing other stuff even if we can get him to sit at his desk. We feel like we always have to push him to study and we are just tired of it."

13Teacher, M, Science High School; "Most students do not read and most of the time they have a hard time understanding what they read, even though they may be intelligent. It is seldom that they give totally irrelevant answers to questions asked during lessons or in their exams."

17Parent, F, Anatolian High School; "We used to offer our child certain rewards in return for him studying his lessons but this has not been working recently either, not being able to motivate him with the promise of a reward." 
The coded data that build up the third theme "Indiscipline/Self-discipline problem, Impertinence" are listed as "indifference, getting whatever he wants, breaking down the lesson, acting in disciplined, violating rules, setting a bad example, expectation for privilege, getting spoiled, problem, incompatibility, absenteeism, talking without permission, chaos, going to bed late, difficulty in getting up, habit of being late for school, family indifferent to discipline, no compensation, preparation for exam, missing the classes, private teaching institute, no concern for future, puberty, proving oneself, drawing attention and seeming different". The risks that may arise under this theme are listed in Table 1c.

Table 1c. Internal risks that may arise under the theme of "Indiscipline/ Self-discipline problem, Impertinence"

\begin{tabular}{|c|c|c|}
\hline Theme & Risks & Freq. \\
\hline $\begin{array}{c}\text { Lack of } \\
\text { discipline/self- } \\
\text { discipline } \\
\text { problems, } \\
\text { Impertinence }\end{array}$ & $\begin{array}{l}\text { - Students with high rates of absenteeism } \\
\text { and get late for their classes suffer from } \\
\text { low academic achievement } \\
\text { Students who have made a habit of staying } \\
\text { up late do not get enough sleep reflecting } \\
\text { poorly on their school performance, } \\
\text { Topics in the curriculum are not } \\
\text { thoroughly covered due to absenteeism of } \\
\text { students preparing for exams, } \\
\text { Students disregarding classroom rules } \\
\text { interrupt the lesson flow due to talking out } \\
\text { of turn or displaying inappropriate } \\
\text { behavior, } \\
\text { Children who get everything handed to } \\
\text { them on a silver plate at home expect } \\
\text { privileged treatment at school making it } \\
\text { more difficult for them to follow the rules, }\end{array}$ & 9 \\
\hline
\end{tabular}

Nine of the respondents stated that the undisciplined, spoiled and lax attitude of the students had a negative impact on their learning and posed a risk. The following are some quotes from respondents;

8Assistant Principal, M, Religious Vocational High School; "Some students go to bed really late at night and have a hard time waking up in the morning, causing them to get late for school all the time, which most parents do not see as a serious concern. And some teachers do not accept latecomers, causing students to miss out on their lessons, and most of the time it is not so easy to make up for missed hours in the classroom."

12Teacher, M, Anatolian High School; "Especially final year students do not show up at school under the pretext of preparing for exams, causing them to miss out on what is being taught in the classroom. There would anyway be no need for students to seek extra academic support elsewhere if they attended regularly."

5Principal, M, Multi-Program High School; "Some students have their parents under their thumb, getting all their wishes done. And a child who gets whatever he wants with no apparent concern for his future does not care about school, naturally enough. These students expect the same treatment at school, which, when they do not get it, makes them unhappy causing adaptation issues."

14Teacher, M, Multi-Program High School; "Most classrooms have a chaotic environment with students speaking out of turn and sabotaging classroom order."

9Assitant Principal, M, Anatolian High School; "Some children entering adolescence are in a constant effort to prove themselves, get attention and look different. For this reason, they are behaving in an undisciplined way by breaking school rules. This in itself sets a bad precedent for other students and the school order collapses."

The fourth theme "Violence, Disrespect, Rudeness" is comprised of the encoded data as "behavioral disorder, abusive words and behaviors, street, internet, disrespect for the elderly people, fault, manner, rude behavior, motivation, tendency in violence, fight, complaint, family, environment, exposure to violence, family control, insensitivity, violent films, being affected by what is watched, real life, damaging themselves and the environment". The risks that may arise under this theme are listed in Table 1d.

Table 1d. Internal risks that may arise under the theme of "Violence, Disrespect, Rudeness"

\begin{tabular}{|c|c|c|}
\hline Theme & \multicolumn{1}{|c|}{ Risks } & Freq. \\
\hline & $\begin{array}{l}\text { Students being rude and } \\
\text { disrespectful towards their teachers } \\
\text { and friends, swearing and causing } \\
\text { disturbance due to improper }\end{array}$ & \\
Violence, & $\begin{array}{l}\text { behavior learned in different } \\
\text { environments (streets, family etc.), }\end{array}$ & 7 \\
Disrespect, & $\begin{array}{l}\text { Children who are exposed to } \\
\text { Rudeness, }\end{array}$ & (family, school, streets etc.) or who \\
& watch violent movies/play games & \\
& are prone to violent behaviors, & \\
\hline
\end{tabular}

Seven of the participants pointed out that the social environment of students, the films they watched and the games they played were a risky causing them to show violent tendencies and display rude behavior. Some of the participants' views on this issue are as follows;

2Principal, M, Occupational and Technical Anatolian High School; "Some students display extremely inappropriate behavior, using rude and swear words. Children are exposed to environments where they get to hear lots of swear words and witness rowdy behavior, either on the internet or on the streets, which directly reflect on their behaviors."

19Parent, M, Occupational and Technical Anatolian High School; "We are living in an age when the children have no more respect for their parents or teachers. We grew up in an age when we were taught to respect the elderly even when we did not like them but nowadays children are just full of contempt and disrespect for authority."

23Student, F, Science High School; "I can say that some students who act rudely toward other students and 
are disrespectful create a risk. Such students have a demotivating effect sabotaging the classroom."

1Principal, M, Anatolian Religious Vocational High School; "We get complaints about some students who are prone to violence fighting with other students. When we investigate their families and the environment in which these children grew up, we then realize that the majority of them were exposed to violence growing up."

10Assitant Principal, F, Occupational and Technical Anatolian High School; "Many students watch violent films because they cannot be controlled by their parents or some parents simply just do not care. They try to imitate what they see in the movies they watch, hurting themselves and others."

Table 1e. Internal risks that may arise under the themes of "Smoking, alcohol and substance addiction", "Suicide" and "Communication problems, lack of or excessive confidence"

\begin{tabular}{|c|c|c|}
\hline Theme & Risks & Freq. \\
\hline $\begin{array}{l}\text { Smoking, alcohol, } \\
\text { substance addiction }\end{array}$ & $\begin{array}{l}\text { - Students who are alcohol or drug } \\
\text { addicts due to family problems, peer } \\
\text { pressure, psychological distress, } \\
\text { problems, curiosity, } \\
\text { Since discipline is not a priority in } \\
\text { private education institutions such } \\
\text { as preparatory schools and private } \\
\text { learning centers, students attending } \\
\text { those institutions display } \\
\text { undisciplined behavior and acquire } \\
\text { bad habits such as smoking, } \\
\text { High number of students who are } \\
\text { addicts due to easy access to } \\
\text { cigarettes, alcoholic beverages, and } \\
\text { drugs, }\end{array}$ & 6 \\
\hline Suicide, & $\begin{array}{l}\text { Attempts by students to commit } \\
\text { suicide due to disputes between their } \\
\text { parents, teachers or friends, }\end{array}$ & 4 \\
\hline $\begin{array}{c}\text { Communication } \\
\text { problems, } \\
\text { Lack of or excessive } \\
\text { self-confidence, }\end{array}$ & $\begin{array}{l}\text { Students who cannot communicate } \\
\text { properly with their teachers cannot } \\
\text { share their requests and problems } \\
\text { and struggle with their problems } \\
\text { Students with inadequate } \\
\text { knowledge of their intellectual } \\
\text { propensities choos wrong } \\
\text { professions, } \\
\text { Some students choose to wear } \\
\text { unconventional clothes and exhibit } \\
\text { different behaviors in an effort to } \\
\text { prove themselves and look different, }\end{array}$ & 4 \\
\hline
\end{tabular}

The coded data that constitute the themes "Smoking, alcohol and substance addiction", "Suicide" and "Communication problems, lack of or excessive confidence" are as follows: "addiction, wannabe, harmful, prohibition, drug, cigarette, alcohol, age of use, harming oneself, selling alcohol and cigarette to children, smoking, disregarding the prohibition, attempt to suicide, introversion, pangs of conscience, death, problem, desire, sentimentality, domestic problems, opposite sex, intense feelings, obsession, overreaction, discussion, conveying, reluctance to talk, not telling, getting depressed, tutoring, uncontrolled joke, fee, misbehavior, warning, discipline, environment, behavior and friend". The risks that may arise under this theme are listed in Table 1e.

Some of the respondents stated that there were different student-related risks such as smoking, alcohol and substance addiction, suicide attempts, communication problems, excessive or inadequate self-confidence. The following are some quotes from respondents;

11Teacher, F, Occupational and Technical Anatolian High School; "Recently a student at our school was caught with drugs. The age threshold for smoking, alcohol and drug abuse at schools is constantly falling. Kids at this stage start using drugs because they want to be like someone else, which in itself causes them irreparable damage. Despite the prohibition of selling cigarettes and alcohol to children, many stores do not care about the law and sell them anyway."

15Teacher, F, Religious Vocational High School; "Some students are overly introverted and do not wish to talk about their school-related or out-of-school problems. There are students who do not wish to talk even if we understand that there is a problem. Such students can sometimes even try to commit suicide by becoming depressed because they do not tell about their problems to anyone."

4Principal, M, Anatolian High School; "I see many students in front of some private learning/study centers with their teachers and other friends smoking and making inappropriate jokes. Such centers do not warn students when they see bad or undisciplined behavior because students pay them. Students who are accustomed to the lax atmosphere in such centers want to be given the same latitude at school."

7Assistant Principal, F, Science High School; "The students in this age group can be very emotional. Particularly students with problems in their family or engage with the opposite sex in an emotional way tend to overreact to anything that may be said to them. There are even students who commit suicide because they wish to make the person they had an argument with, be it their teacher or parents, and feel guilty about it."

22Student, M, Occupational and Technical High School; "A lot of students at our school smoke weed. I do not know where they get them but they smoke them."

Many of the participants stated that students were not motivated enough due to lack of future goals and objectives for some students and showed little interest in school due to their addiction to technological devices and the internet, barely managing it to knuckle down and study. Some respondents emphasized that the undisciplined, spoiled and impertinent behavior displayed by the students constituted a risk and that there was little willpower showed for the solution of this disciplinary problem. Some of the respondents stated that there were different risks such as smoking, alcohol and substance addiction, suicide attempts, communication problems, excessive or inadequate 
self-confidence.

Table 2 shows the risk areas defined as external risks which cannot be directly controlled by the students but which increase the likelihood and impact of these risks by triggering internal risks.

Table 2. Student-related external risk areas that can occur at schools

\begin{tabular}{|l|l|}
\hline \multicolumn{1}{|c|}{ RISK AREAS } & \multicolumn{1}{|c|}{ THEME/CATEGORY } \\
\hline $\begin{array}{l}\text { Risks that result from the } \\
\text { failure of school principals, } \\
\text { teachers, and assistant staff to } \\
\text { do their jobs properly }\end{array}$ & $\begin{array}{l}\text { Leadership-communication, legislation, } \\
\text { plan-program, budget etc. } \\
\text { Teaching plan-program, Classroom } \\
\text { management, Personal development etc. } \\
\text { Hygiene, Safety, Order etc. }\end{array}$ \\
\hline $\begin{array}{l}\text { Risks that may arise due to } \\
\text { parents not fulfilling their } \\
\text { responsibilities }\end{array}$ & $\begin{array}{l}\text { Attention, expectations, child workers, } \\
\text { home environment, tools-equipment etc. }\end{array}$ \\
\hline $\begin{array}{l}\text { The risks arise due to to } \\
\text { measures not being taken } \\
\text { with regard to the school's } \\
\text { physical condition, safety, } \\
\text { hygiene and student health }\end{array}$ & $\begin{array}{l}\text { Crowded classes, accommodation, } \\
\text { physical spaces (labs, libraries etc.), } \\
\text { technological tools and equipment, } \\
\text { accessibility issues of disabled students, } \\
\text { accidents, injuries, missing students, abuse, } \\
\text { epidemics, bad habits, poisoning etc. }\end{array}$ \\
\hline $\begin{array}{l}\text { Risks that may arise as a a } \\
\text { result of inappropriate } \\
\text { curriculum and legislation }\end{array}$ & $\begin{array}{l}\text { Exams, success point criteria, frequent } \\
\text { changes etc. }\end{array}$ \\
\hline $\begin{array}{l}\text { Cultural - social risks } \\
\text { chist }\end{array}$ & $\begin{array}{l}\text { Internet and television programs, street } \\
\text { culture, divorced and separated parents, } \\
\text { economic situation, etc. }\end{array}$ \\
\hline
\end{tabular}

Duties and responsibilities that are not fulfilled in some areas can pose risks and affect students, as can be seen in Table 2, which shows the external risk areas that may affect students at schools. Some of the participants' views on student-related external risks are as follows;

13Teacher, M, Science High School; "Some parents are putting too much pressure on their children to increase their academic success instead of learning where their children's skills lie. They are expecting their children to do things they have not been able to do as a student. Despite being constantly reminded each child has different skills and propensities, over-ambitious parents cause unnecessary stress in their children."

20Parent, M, Religious Vocational High School; "We have lately heard in the news about lots of students who are being subjected to abuse. You cannot trust anyone anymore. Since this is an issue that cannot be overlooked, the school authorities should take the necessary precautions and should act immediately, even when there is the slightest doubt, for students who are likely to be abused."

14Teacher, M, Multi-Program High School; "Students experience adaptation problems when they change schools during the term. A new classroom environment, new teachers, etc. it takes quite a while to get used to and adapt."

10Assistant Principal, F, Occupational and Technical High School; "Some families do not want their children to go to school, and they make them work in different trades even though they are at school age."

21Student, F, Anatolian High School; "Some assistant principals and teachers are just being too harsh. They find fault with almost everything we do."

16Parent, M, Multi-Program High School; "There are teachers who do not affect the smallest change in a student's life even if they teach them throughout the entire year. Such teachers do not do their jobs properly. They start classes late and leave early, get sickness leave for extended periods of time, focusing on other things.

11Teacher, F, Occupational and Technical High School; "Many students are allowed to go to pass even when they do not deserve it. And such students struggle with understanding what is being taught and disrupt the lesson flow due to the level of difference with other students, slowing others down in the process. I think not all students should be allowed to pass."

Concerning factors related to students but beyond their control, the participants provided opinions on various risks such as risks that result from the failure of school principals, teachers and assistant staff to do their jobs properly, risks that may arise due to parents not fulfilling their responsibilities, the risks that may arise due to measures not being taken with regard to the school's physical condition, safety, hygiene and student health, risks that may arise as a result of inappropriate curriculum and legislation and cultural and social risks.

\section{Conclusions and Discussion}

Prerequisite for struggling the risks identified according to internal control is that the standards (Ethical Values and Honesty, Mission, Organization Structure and Duties, Personnel Qualification and Performance, Authority Delegation) of the "Control Environment" part of Internal Control should be well-established in the institution. That's because the "Control Environment" component provides a basis for other components of internal control by ensuring consciousness and awareness for employees of the organization to cope with risks in accordance with internal control. Otherwise, if there is a disruption in the control environment component, other components will not be able to operate properly for fighting off the risks.

The themes created according to the views of the participants and the risks covered by these themes are discussed below in comparison with the previous research.

\section{With regards to risks caused by the addiction} of students to technology;

With the widespread use of communication tools, technological devices, and the internet, which connect people with a single click, online communication has now become the preferred mode of communication for those even sharing the same environment.

The use of technological devices such as computers, smart phones and tablets, and the games in these devices 
enables children to acquire computer literacy and hand-eye coordination, developed spatial skills, imagine, explain the causes of shapes, visualize objects related to chemistry and physics, integrate the shapes in space [40]; however, when overused, it has many psychological negativities such as showing obsessive and aggressive behaviors, tendency to violence, personality changes, decrease of emotions and feelings, development of antisocial behaviors, loss of free thought and desire, increasing level of anxiety, avoidance and boredom of reality and chaos, confusion between dream and reality as well as negative biological effects like hyperactivity, early transition from childhood to adulthood, hand, shoulder, spine appearance and psychomotor skills disorders deriving from lack of activity and movement, weight and vision loss, headache, eye strain, constant fatigue and sleepiness [41, 42, 43].

Furthermore, it can also cause personal and social problems such as low academic achievement, failure to do homework, lying about games, aggressive attitudes, and deteriorating interpersonal relationships [44].

Dependency is defined as the inability to control an action or resist using an object whereby the person in question cannot continue life without using that object or acting in a certain way whether he or she wants it or not [45]. The type of dependency, which is non-chemical (behavioral) and involves human-machine interaction, is defined as addiction to technology. As far as addiction to technology is concerned, interaction can be passive (television, etc.) or active (internet, computer, mobile phone games, etc.) [46].

Young people spend time on the internet for reasons such as having fun, relaxing or using the internet for social interaction as well as not confronting problems, suppressing troubles and escaping from real life. It was stated that the internet, which is not a developer and is extremely misused, starts to turn into problematic use over time, negatively affects the young in terms of both academic and personal development, and makes them addicted $[44,47,48]$.

Technology dependency can heal spontaneously without treatment, but it leaves behind serious harm to the academic and social life of an individual. The most obvious reason for addiction to technology and the internet is not getting enough satisfaction from other areas of life. This can lead to a vicious cycle that prevents a person from socializing, pulling him away from real life activities. People with this kind of addiction get easily bored in environments with people unfamiliar with computers or the internet. In addition, excessive alcohol abuse, pathological gambling, attention deficit, anxiety disorders, depression, hyperactivity disorder, obsessive-compulsive disorder, personality pathologies and other behavioral problems are more frequently seen in technology addicts than in the general population [49].

Researches as to the excessive and adverse use of technological devices and the Internet have revealed that it increases and poses a risk, especially in adolescents in many countries $[50,51,52,53,54,55]$.

Based on research findings and previous studies, if left untreated, addiction to technology can leave a person socially debilitated and isolated to the extent where the affected person will have almost no time for other activities other than those he has to do or people other than those he has to be in contact, causing serious physical, psychological and sociological damage.

For this reason, it can be stated that technology addiction is an important risk that needs to be tackled systematically and rigorously for the future of students.

There are basically four methods of responding to the risks identified according to internal control. These are the acceptance of risk, the control of risk, the transfer of risk and the avoidance of risk. In this regard, unlike other institutions and private enterprises, it is necessary for schools to determine which method(s) should be used to respond to risks, what kind of controls (measures) to be developed, and to apply them in a disciplined way.

\section{With regards to risks posed by students not} being motivated enough and putting off their responsibilities and not studying their lessons;

While some students are more willing and determined to overcome the challenges they face, it is difficult to make generalizations on students' attitudes towards the school and their lessons due to their constantly postponing their duties and responsibilities and avoiding facing their troubles or accepting failure from the beginning instead of taking on the challenges that come their way.

Defined as "the internal stimulus that pushes the organism into action and directs the action" and/or "the conscious or unconscious reasons given for actions that cause a person to channelize his energies toward a certain goal" [56] motivation is one of the factors why some students choose to fight off their troubles while others do not. Motivation gives the individual energy making him or her more willing to cope with problems. How a person gets motivated and to what extent may vary according to many influences such as the person's past, future goals, current environment, social circle and socio-economic level [57].

Research shows that a major portion of discipline incidents observed in the school and the classroom and learning difficulties is associated with motivation and that there is a strong positive relationship between motivation and success and that the increase in motivation allows teachers and students to enjoy school more [58].

According to Yüksel [59], a properly motivated student helps the teacher conduct his lessons according to plan as well as providing a significant source of job satisfaction for the teacher.

In his research, Ulusoy [60] states that some of the sources of motivation come from within the student and 
these are related to "individual goals and intentions, biological and psychological impulses and needs, self-definition, self-confidence and self-esteem, individual beliefs, values, expectations and definitions of success or failure, self-consciousness, self-experiences and self-efficacy and personal factors" and that some emanate from external resources and these are "objectives and expectations of teachers, parents, and friends, results of social interactions, reward and punishment systems, instructional stimuli such as uncertainty, novelty and complexity, performance models, and interesting teaching practices that lead to success and help develop self-confidence".

A study by Altun [61] on the academic failure of the students conducted with the participation of a group of students, teachers, and parents highlights the lack of interest and motivation among the students. In this research teachers, parents and students cite "a lack of understanding of the purpose of the school by the students, the lack of reading habits of the students, failure of students to set goals, not studying according to a plan, getting easily bored when studying, not doing homework, studying only when there is an exam, not revising what has been taught at school and not listening to the teacher" as reasons for failure at school.

It is important for institutions to determine the risks and fight against these risks as it is for the person to diagnose a disease that is caused by a virus transmitted to the body and fight against this disease. Otherwise, like disease viruses, risks that cannot be diagnosed correctly and adequately intervened cannot be controlled, they can become insurmountable and dead loss can be caused.

In this regards, unless measures are taken to tackle issues with regards to students not being motivated enough at school and postponing their responsibilities and help students increase their knowledge, experience, and insights so that they can deal with problems in life more easily, they will remain as risks with negative impact on academic and social success.

3. With regards to risks created by the undisciplined, spoiled and lax attitude of students which have a negative impact on their lessons and learning patterns;

The lack of discipline and lax behaviors of students that ignore the rules is a class of unwanted behaviors that negatively affect the student and the other students because they pose educational obstacles making it difficult to reach the targeted positive behaviors.

Undesirable behaviors are defined as behaviors in school or classroom that violate the pre-determined written or non-written rules, trample on or violate the common rights of students and teachers, negatively affect educational goals, plans, and activities, and disrupt the lesson flow [62, $63,64,65,66,67]$.

If undesirable behavior both inside and outside the classroom becomes commonplace, the school is dragged into a chaos and the other students are stripped of their right to receive education.

When the causes of undesirable behaviors in schools are taken into consideration, many disciplinary problems have their roots in teachers, students, the classroom structure, school, and family. The role of the school in disciplinary problems has been put forward in four ways: Teaching non-practical things that serve no purpose in real life and not teaching as required, the inadequacy in teaching of students' thinking skills, the wrong attitude of teachers towards students and punishment-driven policies at schools, and the inadequacy of school guidance services. Besides, the physical structure of the class which is not the desired quality, the ambiguity of the school and class rules, teacher quality, problems in domestic relations and economic problems, biological or psychological disorders that students have, and friend pressure also result in occurrence of problematic behaviors at schools $[65,67,68,69]$.

Başar [50] emphasizes that most of the unwanted behaviors within the classroom originate from events outside the classroom. The family environment and the school, in which the learner lives, are the main sources of student behaviors. The educational levels of people living in the same environment are significantly influential on the behaviors of the students and are fed into the classroom reflecting on the behavior of the students.

In a research conducted to reveal perceived risks and threats by school principals and teachers at schools, the level of the students' ability to control their behavior, classroom behavior that can be described as "mischief", "foolhardiness", "laziness" and "noisiness" and unusual student behaviors aberrant from the norms are defined by teachers and principals as risky behavior [70].

Based on all that, it can be indicated that as in all social and behavioral incidents unwanted student behaviors do not have a single cause and that they can emerge due to many factors such as the student himself, the teacher, the family, the class structure, the school environment, the society and that frequent occurrence of such sort of behavior will pose a major risk having a positive impact on teaching activities at schools.

4. With regards to risks caused by the social environment of students, the films they watch and the games they play causing them to show violent tendencies and display rude behavior;

Violence, which has various meanings such as "Brute force", "Excessive display of emotions and uncontrolled behavior", "Using brute forces against those with opposite views" [71], appears frequently in mass communication tools such as the TV or on the internet both on a personal and social basis exerting a negative impact on both children and adults.

According to Sar1 [72], the characters in the games children play on computers, tablets or mobile phones and 
many heroes we see in movies use violence instead of human relations and communication to solve problems setting a negative precedent for children and young people and causing them to think problems can be solved with violence and rudeness.

A research conducted by Özgür et. al. [73], indicates that $10.3 \%$ of the students are exposed to violence and more than half of these students (51.4\%) experience violence at the hand of their friends. In this study, the most common type of violence was "physical violence" and the most perceived form of violence was "beating". Factors influencing the tendency of violence were found to be the gender of the students, their social class, and the economic status of their family.

Children who are exposed to violent computer games and TV broadcasts uncontrollably and constantly and get used to violence show the same behaviors in real life. They can solve their problems in the virtual world by pressing a button, but they cannot solve the problems they face in real life. In addition, the virtual environment is able to easily connect people who are far from each other by removing the limitations imposed by time and space. People who want to communicate with each other without even bothering to meet face to face and get to know each other get the chance to assume a desired personality, role, character, or display excessive behavior through the internet [74].

A study conducted collectively by Istanbul Bilgi University, Dokuz Eylül University Law School and Hannover Criminology Institute on violence against children shows that $18.5 \%$ of children resort to violence due to lack of education, $17.9 \%$ due to uncaring parents and $17.3 \%$ due to violent broadcasts, programs, and games [75].

In a research conducted by Tekşen [70], to determine the risk perceptions of school principals and teachers, teachers and principals cite 'the level of respect shown by students both inside and outside the classroom, the impact of negative social events on student behaviors, lack of fear of authority and teachers on the part of students unlike 15-20 years ago, the generational gap between teachers and students, media, computer games and how violence is represented in movies, and the disregard of some students for basic principles such as integrity and respect on the path to success' as risk factors.

There is a lot of research about the tendency to violence in children and the causes of violence. While these surveys indicate that the tendency to violence has many reasons, there is a consensus on the view that programs broadcast on mass media (TV, computers, phones etc.) that are becoming widespread in parallel with technological developments and that contain violent content with lots of swearing and rude behavior have a negative impact on children as well as disrespectful/rude behaviors and violent events children witness in their families and the social circle they live in. It can be concluded that violence and rude behavior are important risks to be tackled in schools.

5. With regards to risks caused by students taking up habits such as smoking as well as alcohol and substance addiction, suicide attempts, communication problems, excessive or inadequate self-confidence;

During puberty when one is in search of an identity, risk-taking behaviors are more frequent and smoking, alcohol and drug abuse can occur more easily, a peaceful family environment and social circle will ensure a healthier mental development of the child while a problematic family and a social environment would pose a risk for smoking and alcohol abuse and suicide attempts.

Many studies show that smoking, alcohol and substance abuse is more prevalent among young people coming from troubled families and a negative social environment, being an important factor that triggers habits such as smoking and alcohol abuse [76, 77, 78].

Another factor related to the frequent use of cigarettes, alcohol, and drugs among students is easy accessibility. Ögel et al. [79], found that $60.7 \%$ of the students can easily access alcoholic beverages, and this rate was $12.1 \%$ for cannabis, $30.3 \%$ for volatile substances, $8.2 \%$ for heroin, $8 \%$ for cocaine and $8.5 \%$ for ecstasy.

According to statistics, even though suicide death ranked low among the leading causes of death in Turkey in the 1990 s, it is thought that young deaths have increased in recent years especially as a result of suicide attempts and suicide is seen as an important problem in our country as well as in the world $[80,81,82]$.

In a study conducted by Kara et al. [83], with high school students, $18 \%$ (59\% female, $41 \%$ male) of students had suicidal thoughts over the last one year and $9 \%$ of the students (55\% female, $45 \%$ male) attempted suicide. Güler et. al. [84], found that $19 \%$ of the students thought of suicide over the last year, $15.5 \%$ of them smoked and $4.4 \%$ of them drank alcohol. Other studies have also shown that problems in the family and social environment are closely related to smoking, alcohol, drug abuse and suicide attempts $[84,85,86,87]$.

In another survey on this subject, $53 \%$ of students from broken families were reported to play with suicidal thoughts in the past while $30 \%$ of them were reported to attempt suicide [86].

As can be inferred from these data, suicide attempts, as well as smoking, alcohol and substance abuse, constitute an important risk for young people.

As stated in the 'information and communication' component of internal control, it is necessary to establish a strong communication network between administrators, teachers, students, parents and students in order to effectively cope with the risks.

6. In addition, in accordance with the literature on the subject and the opinions received from the participants, the following student-related risks that are beyond the students' control have been identified: 
risks that result from the failure of school principals, teachers and assistant staff to do their jobs properly, risks that may arise due to parents not fulfilling their responsibilities, the risks that may arise due to measures not being taken with regard to the school's physical condition, safety, hygiene and student health, risks that may arise as a result of inappropriate curriculum and legislation and cultural and social risks.

According to the internal control system, the risks identified by the relevant shareholders need to be evaluated at the next stage for impact and probability. As a result of this evaluation, controls (measures) should be developed to reduce the risks with high points.

Controls are applications, policies, procedures, systems, processes and actions that function to reduce risks in an organization. Control types are generally classified as preventive, detective, directive, corrective and compensatory controls [88].

Once the risks are identified and assessed for impact and probability, then it is necessary for the shareholders of that control to determine which of these control types will be employed against the particular risk.

\section{Recommendations}

The suggestions related to the risks identified within the scope of the research are listed below.

1. Proposals on the use of technology/internet to prevent and control the risk of students' technology/internet dependency;

- Families should not just throw their children in a corner by giving them technological devices like opium, but rather encourage them to engage in sport activities, develop hobbies and games outside the virtual space.

- Children should be encouraged to spend time with their friends in social settings (cinema, theater, museum, sporting activities).

- An example should be made to help children develop a taste for reading by creating tech-free hours at home. Because actually doing something rather than merely talking will have a more profound impact on children.

2. Suggestions for preventing and controlling the risks associated with students not being motivated enough due to the lack of future goals and their delaying their school duties and responsibilities;

- Parents should be encouraged to assign duties to their children around the house from an early age.

- Children's intellectual capacities, individual abilities, socio-economic-cultural backgrounds, attitudes towards the school should be identified by parents and teachers and guidance should be given to students in setting targets according to their interests and abilities.

- Emphasizing their positive aspects, they should be motivated to reach their goals, providing guidance on the ways and methods of doing it.

- Students should be given opportunities during both lessons and extra-curriculum activities to design and develop exciting and intellectually invigorating activities whereby they develop skills for lifelong learning and development.

3. Proposals on preventing and controlling risks with regards to the undisciplined behavior of students;

- Since a patient, honest, loving, consistent, determined, and understanding teacher and parent are the most important factor determining the attitude of a student towards school and life, it will have a far greater impact on students to display correct behavior as an experiential model instead of just giving advice.

- Since ignoring recurring negative student behaviors lead to repetition of such behaviors, it is necessary to explain the correct behavior expected from the student using a positive language when a negative behavior is displayed.

- Since the inconsistency between teachers' and parents' attitudes and behaviors will lead to a decrease in learning motivation for students, educators and parents from all levels of the education system must demonstrate a consistent approach to discipline.

4. Recommendations with regards to preventing risks caused by the social environment of students, the films they watch and the games they play causing them to show violent tendencies and display rude behavior;

- Families and students should be enabled to have awareness of violence and the causes of violence by providing training on effective problem-solving methods without resorting to violence.

- Educational programs for parenting and family relationships should be promoted.

- Tighter control of violent broadcasts and news. Families should impose restrictions by controlling TV and internet broadcasts that children are exposed to.

- Increasing student awareness of physical, emotional, sexual and economic dimensions of violence by giving the subject matter of violence more room in educational programs and designing environments where they can say "no" to violence.

- The sources of youth violence tendencies should be identified and psychological support should be given to rehabilitate young people exposed to domestic violence in their childhood.

5. Recommendations for preventing and 
controlling the risks caused by students taking up habits such as smoking as well as alcohol and substance addiction, suicide attempts, communication problems, excessive or inadequate self-confidence;

- In order to prevent substance abuse and suicide attempts, which have serious consequences, programs on family relationships should be organized to ensure that young people can express positive and negative feelings easily, establish empathy, communicate with others, develop effective problem-solving skills, learn to share responsibility and avoid risky behaviors.

- In order to prevent suicide attempts and drug addiction, more training should be given to teachers, parents, and students on mental health problems and all kinds of words and behaviors related signaling suicidal tendencies need to be taken seriously.

- Students should be prevented from being in environments where they can easily access cigarettes, alcohol, and drugs.

- Comprehensive counseling services should be provided to ensure that the families perform their functions in a healthy manner.

- $\quad$ Psychological training should be given to ensure that students develop skills that enable them to tackle the problems they face and hold on to life and prevent them from falling into the trap of despair.

Finally, considering that parents and teachers are role models for children/students and that most of their behaviors reflect behavior patterns seen at home and at school, parents and teachers should be more careful in situations that can cause risky behaviors.

It is also recommended by researchers to other researchers to conduct further researches into what other controls (measures) should be developed regarding the risks identified in this study as well as the risky situations in other areas of schools which may have an adverse effect on the educational activities of the students.

\section{REFERENCES}

[1] Açıkalın, A., Şişman, M. ve Turan, S. (2011). Bir İnsan Olarak Okul Müdürü. Ankara: Pegem Akademi.

[2] Şahin, S., ve Aslan, N., (2008). İlköğretim Okul Yöneticilerinin Stratejik Planlamaya İlişkin Görüşleri Üzerine Nitel Bir Çalışma (Gaziantep İli Örneği), Gaziantep Üniversitesi Sosyal Bilimler Dergisi, 7(1):172-189

[3] Akyüz, Y. (2010). Türk Eğitim Tarihi MÖ 1000-MS 2010, 18. Bask1, Ankara, Pegem Akademi.

[4] Steiss, A. W. (2003), Strategic Management for Public and
Nonprofit Organizations, New York: Marcel Dekker Inc.

[5] Bryson, J. M. (2004). Strategic Planning for Public and Nonprofit Organizations, 3. Edition, San Francisco: Jossey-Bass A Wiley Imprint.

[6] Gençkaya, Ö. F., Gündoğdu, H. G., (2017). Küresel Yönetişim Ekseninde Stratejik Planlarda Koordinasyonun Önemi, Marmara University Journal of Political Science, Cilt 5, Özel Say1, Nisan, ISSN 2147-6934, ss. 125-137

[7] Demirkaya, D. (2007). İlköğretim Okullarında Stratejik Planlama Uygulamalarının Değerlendirilmesi.

Yayımlanmamış Yüksek Lisans Tezi, Ankara Üniversitesi, Ankara.

[8] Memduhoğlu, H.B. Taşdan, M. Erdem, M. (2008). İlköğretim okullarında stratejik planlama uygulamalarının değerlendirilmesi. Proceedings of Conference on. (1368-1380) Famagusta, North Cyprus. Department of Educational Sciences Faculty of Education.

[9] Özdem, G. ve Çakır, R. (2009). Eğitim Örgütlerinin Strateji Planlarında Yer Alan Vizyon ve Misyon Cümlelerinin Değerlendirilmesi (Giresun ili örneği). Uluslararas1 5.Balkan Eğitim ve Bilim Kongresi (190-194), Edirne: Trakya Üniversitesi Eğitim Fakültesi.

[10] Altınkurt, Y. (2010). Milli Eğitim Müdürlüğü Çalışanları ve Okul Yöneticilerinin Stratejik Planlamaya İlişkin Tutumları. Kuram ve Uygulamada Eğitim Bilimleri Dergisi, 10 (4). 1927-1968.

[11] Yelken Y. T., Kılıç, F. ve Üredi L. (2010). Stratejik Planlama Uygulamalarına Ilişkin İlk ve Orta Öğretim Okul Müdürlerinin Görüşleri. Uluslararası Avrasya Sosyal Bilimler Dergisi, 1, 38-50.

[12] Kocatepe, Ş. (2010). Eğitimde stratejik planlama ve toplam kalite uygulamalarının okul yöneticileri tarafindan algılaması. Yayımlanmamış Yüksek Lisans Tezi. Marmara Üniversitesi, İstanbul.

[13] Küçüker, E. (2010). Türkiye'de Eğitim Planlaması Neyi Hedefliyor? International Conference on New Trends in Education and Their Implications, 153-157.

[14] Balcı, A., Çanakçı, H. ve Tan, Ç. (2012). Elazı̆̆ İli, İlköğretim Okullarında Hazırlanan Stratejik Planlar İle İlgili Okul Yöneticisi ve Öğretmen Görüşleri. Elektronik Sosyal Bilimler Dergisi, 39 (11), 385-394.

[15] Balkar ve Ekici, (2015). Examining the Relationship Between Practices of Strategic Planning and Organizational Communication in Primary Schools According to the Opinions of Teachers", Turkish Studies -International Periodical for the Languages, Literature and History of Turkish or Turkic-, ISSN: 1308-2140, Volume 10/11 Summer, Ankara/Turkey

[16] Memduhoğlu, H., B., Uçar, İ. H., (2012). Yönetici ve Öğretmenlerin Stratejik Planlama Algısı ve Okullarda Mevcut Stratejik Planlama Uygulamalarının Değerlendirilmesi, Mehmet Akif Ersoy Üniversitesi Eğitim Fakültesi Dergisi, 12, (23), 234-256

[17] Arslan, G., Küçüker, E., (2016). Planning Activities of School Principals and Problems Encountered in Strategic Planning, Mart Cilt:24 No:2 Kastamonu Education Journal, March, Vol:24, No:2, p:839-856 
[18] Ereș, F., (2004). Eğitim Yönetiminde Stratejik Planlama, Gazi Üniversitesi Endüstriyel Sanatlar Eğitim Fakültesi Dergisi, Sayı:15, s.21-29,

[19] Isşk, H., Aypay A. (2004). Eğitimde Stratejik Plan Geliştirme Sürecinde Karşılaşılan Sorunlar: Çanakkale İlinde Yapılan Bir İnceleme. Gazi Üniversitesi Eğitim Fakültesi Dergisi. Cilt.24 Say1:3, 349-363.

[20] Tunç, İ. (2014). Kurumsal Risk Yönetim Sisteminin Stratejik Planlamanın Başarısı Üzerindeki Etkisi, Mali Hizmetler Uzmanlığı Araştırma Raporu, Yalova Üniversitesi Strateji Geliştirme Daire Başkanlığg.

[21] Derici, O., Tüysüz, Z. ve Sar1, A., (2007). Kurumsal Risk Yönetimi ve Sayıştay Uygulaması. Sayıştay Dergisi, Sayı:65: 151-17.

[22] Online available from https://tr.wikipedia.org/wiki/Risk

[23] İç Denetçilerin Çalıșma Usul ve Esasları Hakkında Yönetmelik, Madde 4 (Regulation on Working Procedures and Principles of Internal Auditors, Article 4)

[24] Alptürk, E., (2008), Finans, Muhasebe ve Vergi Boyutlarında İç Denetim Rehberi, Maliye ve Hukuk Yayınları, Ankara.

[25] COSO Enterprise Risk Management, Integral Framework, (2004), Online available from https://www.coso.org

[26] Uzunay, V., (2007), Avrupa Birliğinde ve Türkiye’de Kamu İç Mali Kontrol Sistemi ve $\mathrm{Bu}$ Alanda Yapılan Düzenlemeler, T.C. Maliye Bakanlığı Bütçe ve Mali Kontrol Genel Müdürlüğü, Ankara

[27] Pickett, K. H. S., (2010). The Internal Auditing Handbook, United Kingdom: Wiley\&Sons, 3rd ed.

[28] Pehlivanl1, D., (2010), Modern İç Denetim - Güncel İç Denetim Uygulamaları, İstanbul, Beta Yay., s.67.

[29] Kamu İç Kontrol Standartları Tebliği. (2007). T. C. Resmi Gazete, 26738, 26 Aralik 2007. Online available from http://www.resmigazete.gov.tr/eskiler/2007/12/20071226-2 1.htm

[30] Saltık, N., (2007), İç Kontrol Standartları, Maliye Bakanlığı Bütçe ve Mali Kontrol Genel Müdürlüğü İç Kontrol Merkezi Uyumlaştırma Dairesi, Ankara, Online available from http://kontrol.bumko.gov.tr/Eklenti/6855,saltik-nihal-ic-kon trol-stanadrtlari-arastirma-raporu.pdf?0

[31] Kamu İç Kontrol Rehberi. (General Public Internal Control Guide), Maliye Bakanlığı Bütçe ve Mali Kontrol Genel Müdürlüğ̈̈, (2014), Online available from http://www.pergen.gov.tr/icerik/pdf/8227 kamuickontrolre hberilversiyon 12.pdf.

[32] Tuan, K., (2009), Bağımsız Denetim Sürecinde İç Kontrol Sisteminin İncelenmesi ve Değerlendirilmesi, Çukurova Üniversitesi İİBF Dergisi, Cilt: 13, Say1: 2, s. 3;

[33] Güner, M. F., (2009), Kamu İdarelerinin Etkin Yönetiminde İç Kontrol Uygulamalarının Rolü. Maliye Dergisi, Sayı 157,

[34] Research Triangle Institute, (2004), Guide Pratique De La Planification Strategique Participative Dans Les Collectivités Locales, North Carolina, USA: RTI Internationale.
[35] Köse, A., Dös, İ., Risk Tabanlı Denetimin Eğitim Alanında Uygulanabilirliğinin Maarif Müfettişlerinin Görüşlerine Göre İncelenmesi. İnönü Üniversitesi Eğitim Fakültesi Dergisi, (2014), Ağustos, 15(2), s. 45-64

[36] Yıldırım, A. ve Şimşek H. (2013). Sosyal Bilimlerde Nitel Araştırma Yöntemleri. (9. Baskı). Seçkin Yayıncılık. Ankara.

[37] Karasar, N. (1995). Bilimsel Araştırma Yöntemi. 3A Araştırma Eğitim Danışmanlık. Ankara.

[38] Miles, M, B., \& Huberman, A. M. (1994). Qualitative data analysis: An expanded Sourcebook. (2nd ed). Thousand Oaks, CA: Sage.

[39] Bilgin, N. (2000). İçerik çözümlemesi. Ege Üniversitesi Edebiyat Fakültesi Yayını. İzmir.

[40] Cesarone, B. (1994, Ocak). Video Games and Children. ERIC

Digest.http://www.kidsource.com/kidsource/content2/video .games.html

[41] Hauge, M. R., \& Gentile, D. A. (2003, April). Video game addiction among adolescents: Associations with academic performance and aggression. Poster presented at the 2003 Society for Research in Child Development Biennial Conference, Tampa, FL. http://www.psychology.iastate.edu/FACULTY/dgentile/SR CD\%20Video\%20Game\%20Addiction.pdf.

[42] Chiu, S. I., Lee, J. Z., \& Huang, D. H. (2004). Video game addiction in children and teenagers in Taiwan. CyberPsychology \& Behavior, 7(5), 571-581.

[43] Wan, C.S. ve Chiou, W.B. (2006). Why Are Adolescents Addicted to Online Gaming? An Interview Study in Taiwan. Cyberpsychology \& Behavior, 9(6), 762-766.

[44] Canoğullari, Ö. ve Güçray, S. S., (2017). Examination of Adolescents with Different Levels of Internet Addiction in Terms of Psychological Needs According to Gender, Social Anxieties and Perception of Parental Attitudes C.Ü. Sosyal Bilimler Enstitüsü Dergisi, Cilt 26, Sayı 1, Sayfa 42-57 42

[45] http://tbm.org.tr/media/1152/04 lise tekno.pdf adresinden 13.07.2017 tarihinde erişilmiştir. Online available from http://tbm.org.tr/media/1152/04 lise tekno.pdf

[46] Griffiths, M.D., (1995), Technological addictions, Clinical Psychology Forum, 76, 14-19

[47] Cengizhan, C. (2005). Öğrencilerin bilgisayar ve internet kullanımında yeni bir boyut: Bağımlılık. VIII. Ulusal Psikolojik Danışma ve Rehberlik Kongresi'nde sunulan bildiri. Marmara Üniversitesi Eğitim Fakültesi, İstanbul

[48] Ayas, T., Çakır, Ö. ve Horzum, H.B. (2011). Ergenler için bilgisayar bağımlılığ 1 ölçeği. Kastamonu Eğitim Dergisi, 19 (2), 439-448.

[49] Yargıç İ., Davranışsal Bağımlılıklar, Online available from (http://liberteterapi.com/2017/06/02/davranissal-bagimlilikl ar-prof-dr-ilhan-yargic/)

[50] Cao, F. \& Su, L. (2007). Internet addiction among Chinese adolescents: prevalence and psychological features. Child: Care, Health, and Development, 33 (3), 275- 281. 
[51] Mossbarger, B. (2008). Is internet addiction addressed in the classroom? A survey of psychology textbooks. Computers in Human Behavior, 24, 468-474.

[52] Yen J.Y., Yen C. F., Chen C. C., Chen S. H.\& Ko C. H. (2007). Family factors of internet addiction and substance use experience in Taiwanese adolescents. CyberPsychology \& Behavior, 10 (3), 323-329.

[53] Durkee, T., Kaess, M, Carli, V., Parzer, P., Wasserman, C., Floderus, B., et al. (2012). Prevalence of pathological internet use among adolescents in Europe: demographic and social factors. Addiction, 107, 2210-2222.

[54] Hooi, P. S. C. (2010). Influence of parents and peers on internet usage and addiction amongst school-going youths in Malaysia. Doctoral dissertation, Malaysian University, Malaysia.

[55] Kuss, D. J., Griffiths, M. D., Karila, L. \& Billieux, J. (2013). Internet addiction: A systematic review of epidemiological research for the last decade. Current Pharmaceutical Design, 20(25), 4026-4052.

[56] Budak, S., (2000). Psikoloji Sözlüğü. Bilim ve Sanat Yayınları. Ankara:

[57] Akbaba, S., (2006), Eğitimde Motivasyon, Kazım Karabekir Eğitim Fakültesi Dergisi, Say1: 13

[58] Öncü, H., (2004), Motivasyon. Sınıf Yönetimi. (Edit: Leyla Küçükahmet). Nobel Yayınevi, Ankara, 2004.

[59] Yüksel, G., (2004). Öğrenme İçin Motivasyon. Sinıf Yönetimi. (Edit: Şule Erçetin; Çağatay Özdemir). Ankara, Asil Yayınevi,

[60] Ulusoy, A. (2002). Gelişim ve Öğrenme. Ankara, Anı Yayınlar1,

[61] Altun, S. (2009). İlköğretim öğrencilerinin akademik başarısızlıklarına ilişkin veli, öğretmen ve öğrenci görüşlerinin incelenmesi, İlköğretim Online, 8(2), 567-586, 2009. Online available from http://dergipark.ulakbim.gov.tr/ilkonline/article/viewFile/50 00038173/5000037030

[62] İlgar, L., (2000), Eğitim Yönetimi, Okul Yönetimi, Sınıf Yönetimi, Beta Yayıncılık, İstanbul, s. 167

[63] Küçükahmet, L., (2002), Sınıf Yönetimde Çağdaş Yaklaşımlar, Nobel Yayıncılık, Ankara, s.17

[64] Korkmaz, İ. (2003). İstenmeyen Davranışların Önlenmesi. Z Kaya. (Ed.). Sinıf Yönetimi (3. bs.). Ankara: Pegem A Yayincilik.

[65] Öztürk, B. (2005), Sinıfta İstenmeyen Davranışların Önlenmesi ve Giderilmesi, E. Karip (Ed.), Sinıf Yönetimi, Ankara, Pegem A Yayıncılık.

[66] Akçadağ, T. (2007). Sorun Davranışların Yönetimi, Etkili Sınıf Yönetimi. H. Kıran (Ed.). Ankara, Anı Yayınevi.

[67] Gündüz, H. B. \& Konuk, S. (2016). İlkokul öğretmenlerin karşılaştıkları istenmeyen davranışlar ile baş etme stratejileri. Yildiz Journal of Educational Research, 1(1), 37-54.

[68] Celep, C., (2000). Sinıf Yönetimi ve Disiplin, An1 Yayıncilik.

[69] Yalçınkaya, M., Küçükkaragöz, H. (2006). Sınıfta Disiplin
Kurallar1 Belirleme ve Uygulaması. M. Y1lman. (Ed.). Sinıf Yönetimi, (s. 101-132). Ankara: Nobel Yayınları.

[70] Tekşen, K., (2014). Yönetici ve Öğretmen Görüşlerine Göre Eğitimsel Risk Algısı. Yayımlanmamış Yüksek Lisans Tezi, Kastamonu Üniversitesi, Kastamonu.

[71] Online available from http://www.tdk.gov.tr/index.php?option=com gts\&arama= gts\&guid=TDK.GTS.5a0b119c9b88d4.73533611

[72] Sarı, İ., (2017), Televizyon ve Çocuklar, Net Medya Yayıncilik, s.39,

[73] Özgür G., Yörükoğlu, G., Arabacı, L. B., (2015), Lise Öğrencilerinin Şiddet Algıları, Şiddet Eğilim Düzeyleri ve Etkileyen Faktörler, Online available from https://www.researchgate.net/publication/281648029_Lise Ogrencilerinin Siddet Algilari Siddet Egilim Duzeyleri ve Etkileyen_Faktorler_High_School Student $\% 27$ s Perce ption_of_Violence_Level_of_Tendency_to_Violence_and Effective_Factors.

[74] Asagem, (2008), İnternet Kullanımı ve Aile Araştırması, Online available from http://ailetoplum.aile.gov.tr/data/54292ce0369dc32358ee2a 46/internet\%20ve\%20aile.pdf

[75] Öztürk, B. (2001), Şiddet ve Çocuk, Online available from www.kriminoloji.com

[76] Ögel K, Erol B. (2005), Çocuklarda Sigara, Alkol ve Madde Bağımlılığı "Çocuğum Madde Bağımlısı Olmasın", Morpa Kültür Yayınları, Ankara,

[77] Steinberg, L. (2007). Ergenlik. (1. Bask1). (Çev. F. Çok). Ankara: İmge Kitabevi, s.489-499.

[78] Erbay, E., Oğuz, N., Yıldırım, B. ve Firat E., (2016), Alkol Ve Madde Bağimliliği Olan Bireylerin Başa Çikma Tutumlari Türkiye Sosyal Araştırmalar Dergisi, Sayı 3

[79] Ögel K, Tamar D, Evren C, Çakmak D., (2000), İstanbul'da Lise Gençleri Arasında Sigara, Alkol ve Madde Kullanım Yaygınlığ 1 , Klinik Psikiyatri, 3:242-245

[80] Aktepe, E., Kandil, S., Topbaş, M., (2005), Çocuk ve Ergenlerde Özkıyım Davranışı. TSK Koruyucu Hekimlik Bülteni, Say1: 4, 88-97.

[81] Duman M, Özdemir D, Demir K ve ark. (2004), Çocuk Acil Servisine Özkıyım Girişimi İle Başvuran Olguların Özellikleri. Dokuz Eylül Üniversitesi Tıp Fakültesi Dergisi; 18: $236-240$

[82] Uyanıkoğlu, A., Zeybek, E., Cordan Ö., ve ark. (2007), Öntoksikasyon Vakalarının Değerlendirilmesi. Nobel Med; 3: $18-22$.

[83] Kara B, Hatun S, Aydoğan M ve ark. (2003), Kocaeli Ilindeki Lise Öğrencilerinde Sağlık Açısından Riskli Davranışların Değerlendirilmesi. Çocuk Sağlığı ve Hastalıkları Dergisi, 46: 30-37.

[84] Güler, N., Güler, G., Ulusoy, H., Bekar, M., (2009). Lise Öğrencileri Arasında Sigara, Alkol Kullanımı ve Intihar Düşüncesi Sıklığı, Cumhuriyet Tıp Dergisi, 31: 340-345

[85] Eskin, M., (2000), Ergen Ruh Sağlığı Sorunları ve İntihar Davranışıyla İlișkiler, Klinik Psikiyatri; 3: 228-234 
[86] Şimşek, N., Karataş, N., (2011), Nevşehir İl Merkezindeki Lise Öğrencilerinde İntihar Girişimi Yaygınlığı ve İlişkili Ailesel Faktörlerin Belirlenmesi, Aile ve Toplum, Y11: 12 Cilt: 7 Sayı: 25 Haziran, ISSN: 1303-0256

[87] Yalaki, Z., Taşar M. A., Yalçın, N., Dallar, Y., (2011),
Çocukluk ve Gençlik Dönemindeki Özkıyım Girișimlerinin Değerlendirilmesi, Ege Tip Dergisi, 50 (2): 125-128.

[88] Kaya, B., (2015), Kurumsal Performansi Artirmak İçin İç Denetim İç Kontrol ve Risk Yönetimi, Yaklaşım Yayıncılık, Ankara: s. 236-237.

* This article was presented at the 8th International Education Management Forum. It was produced from the second author's doctoral dissertation. 